\title{
Analgesic Activity of a Glucan Polysaccharide Isolated from Agaricus blazei Murill
}

\author{
Maria Leônia C. Gonzaga, ${ }^{1}$ Thiago M. F. Menezes, ${ }^{1}$ José R. R. de Souza, \\ Nágila M. P. S. Ricardo, ${ }^{1}$ Ana L. P. Freitas, ${ }^{2}$ and Sandra de A. Soares ${ }^{1}$ \\ ${ }^{1}$ Department of Organic and Inorganic Chemistry, Federal University of Ceará, P.O. Box 12200, 60455-760 Fortaleza, CE, Brazil \\ ${ }^{2}$ Department of Biochemistry and Molecular Biology, Federal University of Ceará, P.O. Box 12200, 60455-760 Fortaleza, CE, Brazil
}

Correspondence should be addressed to Sandra de A. Soares; sas@ufc.br

Received 9 July 2013; Revised 30 July 2013; Accepted 31 July 2013

Academic Editor: R. J. Linhardt

Copyright (C) 2013 Maria Leônia C. Gonzaga et al. This is an open access article distributed under the Creative Commons Attribution License, which permits unrestricted use, distribution, and reproduction in any medium, provided the original work is properly cited.

\begin{abstract}
A water soluble polysaccharide and its selective precipitated fractions (F1, F2, and F3) were isolated from hot water extract of fruiting bodies of Agaricus blazei Murril known as Agaricus brasiliensis to evaluate the analgesic activity of the materials in Swiss mice. The isolated material and its fractions were characterized by two-dimensional COSY and HMQC spectra as $\beta-(1 \rightarrow 6)-\alpha-$ $(1 \rightarrow 4)$-glucan-bound-protein polysaccharide constituted mainly by $\beta$ - $(1 \rightarrow 6)$ glucan. The glucan-protein polysaccharide and its fractions were analyzed in relation to the protein, carbohydrate, and mineral elements contents. The analysis of the glucan-protein complex revealed a total carbohydrate content of $36.95 \%$ and protein conjugated content of $17.24 \%$. The mineral elements found in larger proportion were $\mathrm{K}, \mathrm{Na}, \mathrm{Ca}, \mathrm{P}$, and $\mathrm{Zn}$. The analgesic activity bioassay of the $\beta-(1 \rightarrow 6)-\alpha-(1 \rightarrow 4)$-glucan bound-protein polysaccharide and its fractions in Swiss mice indicated a significant effect.
\end{abstract}

\section{Introduction}

Several species of mushrooms have presented interesting biological activities. Yim et al. [1] showed that Pleurotus porrigens mushroom was found to have antioxidant activities by several assays methodologies such as DPPH, ABTS, FRAP, and TPC. Polysaccharides isolated from mushrooms have been shown to be effective inducers of NO synthesis in macrophages $[2,3]$. Carbonero et al. studied a $\beta$-glucan from Pleurotus sajorcaju that activated RAW 264.7 macrophages and induced synthesis of NO and of the proinflammatory cytokines TNF$\alpha$ and IL- $1 \beta$, suggesting that the $\beta$-glucan of $P$. sajor-caju has an immunostimulatory effect [4]. Recently, Suseem et al. have reported potent analgesic activity of Pleurotus eous mushroom extracts in Swiss mice, which were mediated via peripheral and central inhibitory mechanisms [5].

The mushroom Agaricus blazei Murill is a fungus species from the family Basidiomycetes. It occurs naturally in the Atlantic Forest in the mountains of São Paulo state, southeast Brazil. The fruit body is appreciated not only for its taste and texture, but also for its nutritional characteristics [6]. Agaricus presents a composition rich in nutrients and poor in calories and fats [6]. Some interesting activities have been observed for Agaricus blazei. It has been shown to reduce the level of blood cholesterol, protecting against coronary diseases [7], and to reduce the level of glucose in the blood [8]. Furthermore, it presents significant contents of proteins, minerals, and fibers such as chitin [6]. The media composition of the dried fruit body contains 35-45\% proteins and $38-48 \%$ carbohydrates constituted mainly by polysaccharides $[9,10]$. Agaricus as well as other species of mushroom in general presents $6-7 \%$ fibers, $5-7 \%$ ashes, $3-4 \%$ fats (including polyunsaturated fatty acids), also vitamins $\mathrm{C}$, E, $\mathrm{H}, \mathrm{K}$, and $\mathrm{B}$ complex, phospholipids, and lectins $[6,10]$. Other constituents with nutritional and therapeutical values such as $\mathrm{Na}, \mathrm{K}, \mathrm{Ca}, \mathrm{Fe}, \mathrm{Mg}, \mathrm{Mn}$, and $\mathrm{Cu}$ minerals have been identified in several mushrooms in quantities ranging from 5 to $7 \%$ [11]. There is also an element-dependent relation to the geographical origin of the fungus $[12,13]$. On the other hand, some elements catalyze reactions at cell-membrane 
level. This may be a path for the understanding of the action of polysaccharides and/or glycoprotein complexes.

The biofunctional characteristic of Agaricus has been related to the presence of constituents such as homo- and heteroglucans with specific configurations types $\beta$ - $(1 \rightarrow 6$ and $1 \rightarrow 3)$ and $\alpha-(1 \rightarrow 6$ and $1 \rightarrow 4)$ and/or glycoprotein complexes $[10,14]$. Some researchers also associate its pharmacological activities to the presence of glycoproteins $[9,15]$ and the dependence of these activities on the existence of the protein-polysaccharide structural bond [9]. However, others consider that this activity is related to the presence of glucans, mainly $\beta$-glucans [16]. To the present, there is no consensus on the subject. Besides $\alpha$ - and $\beta$-glucans, other groups of polysaccharides have also presented therapeutic activities: mannose polymers bound to peptides (mannoproteins) and $\mathrm{N}$-acetyl glucosamines (chitin) [17] and also polysaccharides made up of fucose, arabinose, and rhamnose [18, 19]. Some of these carbohydrates were identified in the polysaccharide isolated from Coriolus versicolor, a Basidiomycete. It presents glycosidic bonds type $\alpha-(1 \rightarrow 4)$ and $\beta-(1 \rightarrow 3)$ [19]. The structural characteristic of polysaccharides has been commonly elucidated by NMR studies that can provide stereochemical configuration, specially the anomeric configuration [20].

Agaricus has been shown to present significant pharmacological potential in the treatment of diseases such as diabetes, hepatitis, lupus, and asthma [21, 22], as well as important anticarcinogenic activity, leukemia included [23, 24]. The active components seem to play a fundamental role in the increased macrophage function and in the resistance to many bacteria, virus, fungi, and infections by parasites, in addition to nonspecific immune stimulation $[25,26]$.

In our previous work [27], it has been shown that the administration of a fraction of $\beta-(1 \rightarrow 6)-\alpha-(1 \rightarrow 4)$-glucanprotein complex polysaccharide extracted from $A$. brasiliensis showed strong in vivo antitumor effect. The test of antiviral activity of aqueous and ethanol extracts from $\beta-(1 \rightarrow 6)$ glucan-protein fraction suggests activity at the initial stage of replication of poliovirus type 1 [25]. In addition, the protective effects of $\beta$ - $(1 \rightarrow 6)$-glucan-protein complex against chemically induced DNA damage in human lymphocytes was also demonstrated [26].

This study deals with the evaluation of the analgesic activity of an isolated polysaccharide fraction of A. blasei. The related fraction was characterized structurally by NMR spectroscopy. Composition, with reference to the content of proteins, carbohydrates, and minerals was analyzed. Aiming to evaluate the analgesic activity of the isolated polysaccharide, several preliminary assays were carried out concerning its analgesic effect in Swiss mice. As far as we know, these achievements shown by the analgesic effects of Agaricus blazei are novel results.

\section{Materials and Methods}

2.1. Mushrooms Origin. Mushrooms were grown in Suzano municipality, SP, Brazil. Raw material was kindly given by Guinish Importação e Exportação de Produtos Alimentícios Ltda.
2.2. Extraction of Water Soluble Polysaccharides. The extraction and isolation of polysaccharides were carried out as described in detail in previous work by Gonzaga [27]. It includes the preparation of $5 \%(\mathrm{w} / \mathrm{v})$ of mushroom in distilled water heating at $100^{\circ} \mathrm{C}$ for 5 hours, and submission to centrifugation. The filtrate with $\mathrm{pH} 5.0$ was neutralized with diluted $\mathrm{NaOH}$ solution. $0.1 \%$ (w/v) $\mathrm{NaCl} /$ volume of the filtrate was added to induce further precipitation in ethanolic medium by adding solution of $5: 1(\mathrm{v} / \mathrm{v})$ ethanol/filtrate. The precipitate was isolated by centrifugation, and hydrogen peroxide (30\%) was used as 1:1 ethanol:peroxide solution to clarify the material, and then, it was submitted to a new precipitation using the same procedure. The precipitate was washed with ethanol, and acetone and dried in a sand bath at $40^{\circ} \mathrm{C}$. After being dissolved in water with stirring for 48 hours at $40^{\circ} \mathrm{C}$, the solution was centrifuged, and the solid precipitate remained was removed. The filtrate was submitted to lyophilization. The dried sample was then submitted to the same procedure described starting from solubilization until obtaining three selective precipitations, hence, F1, F2, and F3. A simple flowchart of the stages is presented in Figure 1. The isolated materials and fractions were characterized by NMR spectroscopy to elucidate its structure and specially its specific configuration and were used to evaluate its analgesic activity in Swiss mice. A further procedure of isolation and identification of $\beta$-glucans was performed according to the method described by Yoshioka et al. [28] and will be published in an upcoming publication.

2.3. Structural Characterization Using Nuclear Magnetic Resonance (NMR). Two-dimensional COSY and HMQC NMR spectra in $\mathrm{D}_{2} \mathrm{O}$-solubilized polysaccharides were obtained in Bruker model Avance DRX-500 at $70^{\circ} \mathrm{C}$. The samples were measured with 4,4-dimethyl-4-silapentane-1-sulfonic acid (DSS) as the internal standard.

2.4. Carbohydrates and Proteins Analysis. The total carbohydrate content for the isolated polysaccharide and fractions $\mathrm{F} 1, \mathrm{~F} 2$, and $\mathrm{F} 3$ was measured by the phenol- $\mathrm{H}_{2} \mathrm{SO}_{4}$ spectrophotometric method [29] using glucose as standard. Spectrophotometer UV-Vis HP 8453 with diode array detector was used for absorbance measurements. The type of monosaccharide present was identified by its alditol-acetate compounds formed in the process after hydrolysis, reduction, and acetylation reactions according to a method previously reported [30]. Alditol-acetate of monosaccharide standard samples of glucose, ramnose, fucose, arabinose, xylose, mannose, and galactose were prepared for comparison. Measurements were carried out in Hewlett Packard chromatograph, model 5890 A, series II with flame ionization detector equipped with J \& W DB-225 $(0.25 \mathrm{~mm}$ i.d. $\times 30 \mathrm{~m})$ column. Nitrogen at $2 \mathrm{~mL} / \mathrm{min}$ was used as carrier gas and acetone was used as an eluent. The protein content of the isolated polysaccharide and F1, F2, and F3 fractions was determined by the Hartree method [31]. Free protein was investigated by the Bradford method [32].

2.5. Mineral Elements Analysis by ICP-AES. Known amounts $(\sim 0.1 \mathrm{~g})$ of samples were weighed in Teflon tubes added with 


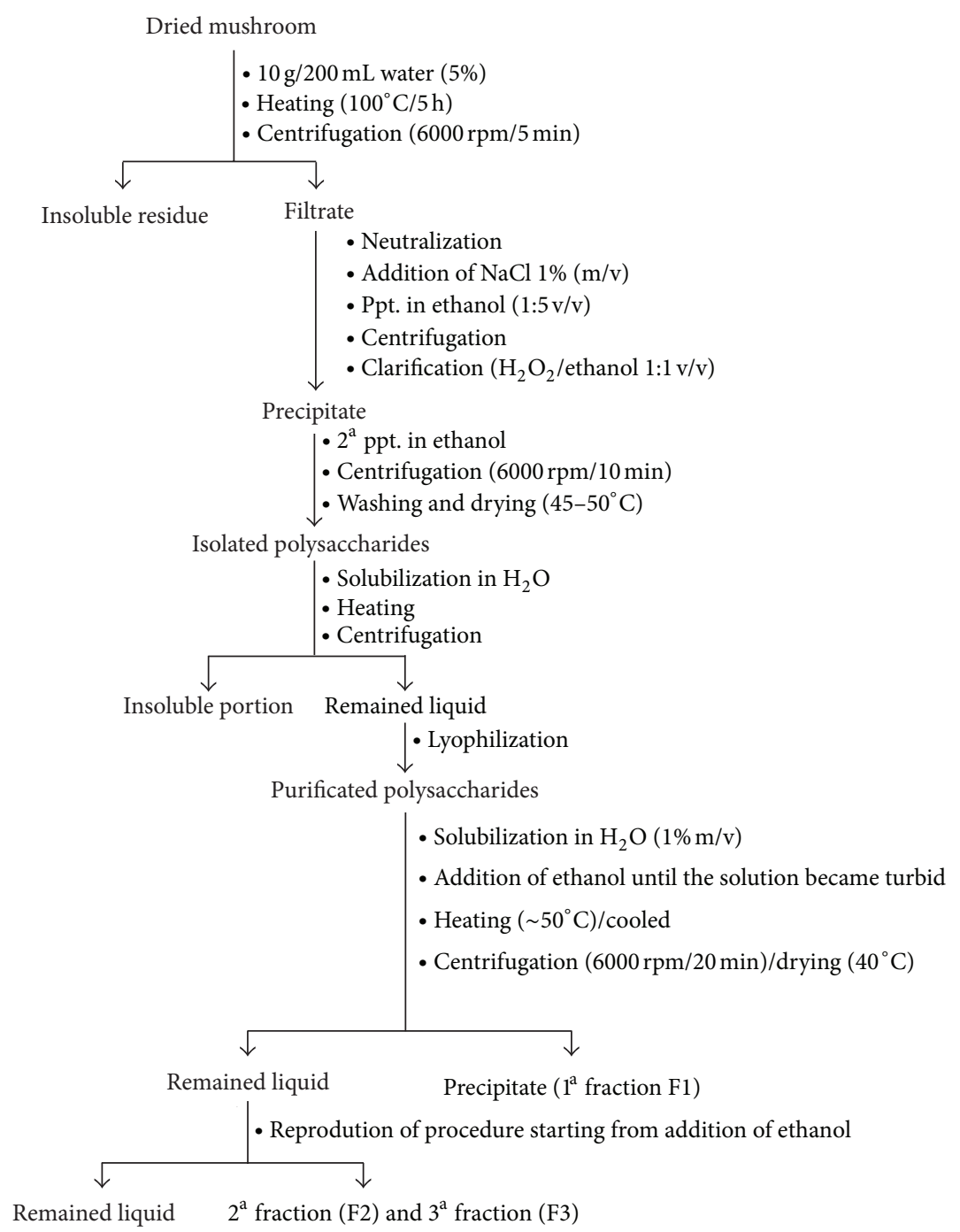

FIGURE 1: Flowchart of the extraction, isolation, purification, and fractionation steps of the polysaccharides.

$3 \mathrm{~mL}$ of $\mathrm{HNO}_{3} / \mathrm{H}_{2} \mathrm{O}_{2} 3: 1 \mathrm{v} / \mathrm{v}$, and heated to $\cong 110^{\circ} \mathrm{C}$ for $3: 30 \mathrm{~h}$ in a digester block. After cooling the tubes, the samples were transferred to Falcon tubes and diluted to a final volume of $20 \mathrm{~mL}$. Standard multielement solutions were prepared in Falcon tubes from standard mineral element solutions of $\mathrm{Ca}$, $\mathrm{Mg}, \mathrm{K}, \mathrm{Na}, \mathrm{Si}, \mathrm{Al}, \mathrm{Ti}, \mathrm{Bi}, \mathrm{V}, \mathrm{Cd}, \mathrm{Cu}, \mathrm{Zn}, \mathrm{Fe}, \mathrm{Pb}$, and $\mathrm{P}$. The standard solutions and samples were injected in the system operating with a radio frequency power of $1350 \mathrm{~W}$ with argon as nebulizing gas, plasma generation gas, and cooling gas at $0.80 \mathrm{~L} / \mathrm{min}, 1.8 \mathrm{~L} / \mathrm{min}$, and $15 \mathrm{~L} / \mathrm{min}$, respectively. The sample mineral elements were quantified with WinLab32 software.

2.6. Analgesic Activity Assay. The analgesic activity of the isolated polysaccharide $\beta$ - $(1 \rightarrow 6)-\alpha$ - $(1 \rightarrow 4)$-glucan-protein complex and of three fractions was evaluated by the method of abdominal writhings induced by acetic acid $0.6 \%$. This test was performed as described for rats [33] and later adapted to mice [34]. Swiss mice weighing between 20 and
$25 \mathrm{~g}$ were used in groups of 06 animals. Each group was pretreated with polysaccharide solutions by intraperitoneal administration (IP) at ratios of 20 and $40 \mathrm{mg} / \mathrm{kg}$ animal. After $30 \mathrm{~min}$, the animals were injected with an algesic agent (aqueous solution of acetic acid $(0.6 \%)$ ) at a ratio of $0.1 \mathrm{~mL} / 10 \mathrm{~g}$ animal. After $10 \mathrm{~min}$, the behavior of the different groups was observed for $20 \mathrm{~min}$ and classified according to the number of writhings (contraction of the abdominal muscles along with extension of hinder legs). The analgesic effect of the samples was measured by the percent inhibition of abdominal writhing. The control group was injected with distilled water $(0.1 \mathrm{~mL} / 10 \mathrm{~g}$ animal $)$ as positive control. The percent inhibition of abdominal writhing was calculated by the following equation:

$\%$ inhibition of abdominal writhing

$$
=100-\left(\frac{\overline{\mathrm{X} C G T}}{\overline{\mathrm{X} C G C}} \times 100\right),
$$




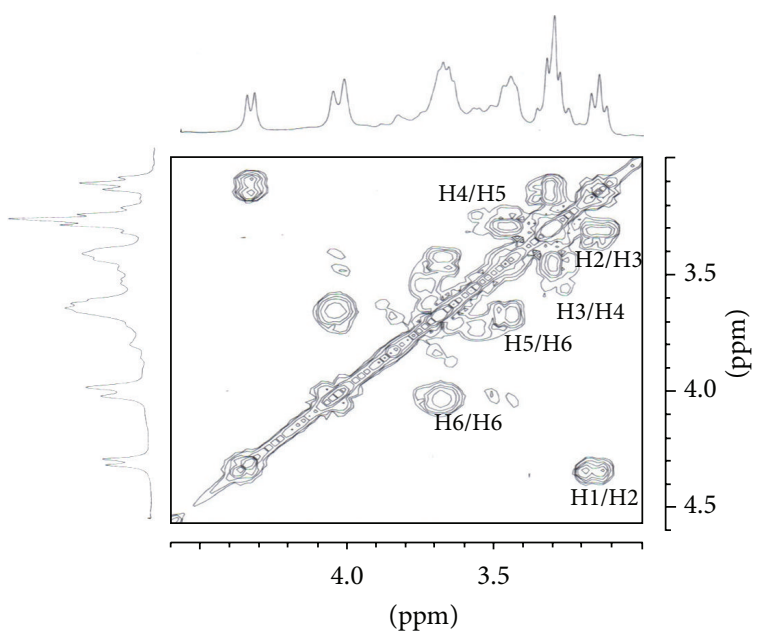

FIgURE 2: ${ }^{1} \mathrm{H}$ NMR, ${ }^{1} \mathrm{HCOSY}$ spectra from isolated polysaccharide.

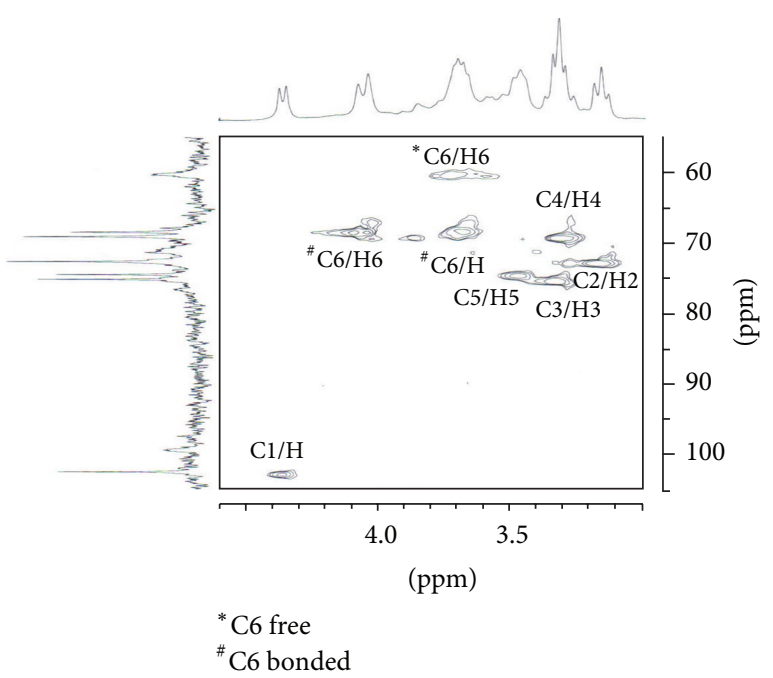

Figure $3:{ }^{1} \mathrm{H}$ NMR, ${ }^{13} \mathrm{C}$ HMQC spectra from isolated polysaccharide.

where $\bar{X} C G T$ is the average writhing of the test group and $\overline{\mathrm{X}} \mathrm{CGC}$ is the average writhing of the control group.

\section{Results}

3.1. Two-Dimensional NMR Structural Analysis COSY and HMQC of Water Soluble Isolated Polysaccharides. Twodimensional spectra COSY and HMQC (Figures 2 and 3, resp.) of the isolated polysaccharide and fractions were used to confirm the attributions in the study recorded by ${ }^{13} \mathrm{C}$ NMR and ${ }^{1} \mathrm{H}$ NMR one-dimensional spectra reported in our previous work [35] that reveled the main structural characteristics of the polysaccharide. The COSY and HMQC data support the first evidence established in the previous paper [35] that the water soluble isolated polysaccharides from Agaricus blazei cultivated in Brazil, as being constituted of $\beta$-(1 $\rightarrow 6)$ and $\alpha$ - $(1 \rightarrow 4)$ glucan-bonded protein complex,
TABLE 1: Molar mass of the fractions by GPC and protein content from polysaccharides and fractions.

\begin{tabular}{lcc}
\hline Sample & \% Carbohydrates & \% Protein \\
\hline Polysaccharides & $36.95 \pm 0.51$ & $17.24 \pm 0.59$ \\
F1 & $39.58 \pm 0.50$ & $6.44 \pm 0.36$ \\
F2 & $33.84 \pm 0.22$ & $40.58 \pm 0.46$ \\
F3 & $15.62 \pm 0.33$ & $57.34 \pm 0.34$ \\
\hline
\end{tabular}

TABLE 2: Concentration of the elements identified in the isolated polysaccharide by ICP-AES.

\begin{tabular}{lc}
\hline Element & Concentration $(\mu \mathrm{g} / \mathrm{g})$ \\
\hline $\mathrm{Al}$ & 54.30 \\
$\mathrm{Fe}$ & 54.52 \\
$\mathrm{Cu}$ & 63.35 \\
$\mathrm{Zn}$ & 113.27 \\
$\mathrm{Ca}$ & 722.37 \\
$\mathrm{Na}$ & 4550.10 \\
$\mathrm{Mg}$ & 4884.19 \\
$\mathrm{~K}$ & 12571.60 \\
$\mathrm{P}$ & 23024.50 \\
\hline
\end{tabular}

are $\beta$ configuration $(1 \rightarrow 6)$ predominant. The chemical characteristic of ${ }^{13} \mathrm{C}$ NMR shifts observed at: 103.0; 73.1; 75.6; 69.5; 74.9; and 68.88 was attributed to the $\mathrm{C} 1-\mathrm{C} 6$ of the glycoside ring relative to $\beta$ - $(1 \rightarrow 6)$. For $\alpha$ - $(1 \rightarrow 4)$, the representative shifts are: 99.8; 71.5; 75.3; 78.7; 71.2; and 60.1. The ${ }^{1} \mathrm{H}$ NMR spectra showed the shifts in the 3.3-4.0 ppm region attributed to the carbon protons (C2-C6) of the glycoside ring [36]. The chemical shifts of the anomeric hydrogens are observed in the 4-6 ppm region. The doublets recorded at 4.1 and $4.2 \mathrm{ppm}$ are characteristic of the $\beta$ - $(1 \rightarrow 6)$ configuration and those in the 4.9-5.6 ppm region are representative of $\alpha$ configuration [10]. Configuration $\alpha-(1 \rightarrow 4)$ is represented by the shift at $5.3 \mathrm{ppm}$. Peaks recorded in the interval of $0.8-3.0 \mathrm{ppm}$ attributed to the protein group protons as groups $\mathrm{N}-\mathrm{CH}_{3}$ and $\mathrm{N}-\mathrm{H}$ were generally observed around $2.78 \mathrm{ppm}$ and in the region of $0.5-$ $3.0 \mathrm{ppm}$, respectively [37]. Glucan of similar configuration was also isolated from Astraeus hygrometricus cultivated in India [38].

Additional NMR data were recorded for $\beta$-glucan sample isolated in procedure 2.3 (data not shown) and the intensity of the peaks recorded regarding glucan $\beta-(1 \rightarrow 6)$ demonstrated that it is the major component in the constitution of the isolated polysaccharide. Similar spectra of ${ }^{1} \mathrm{H}$ and ${ }^{13} \mathrm{C}$ NMR were published for a $\beta$-glucan isolated from Agaricus blazei grown in Japan [9].

3.2. Determination of Total Carbohydrates and Proteins. The total carbohydrate content of the isolated $\beta$ - $(1 \rightarrow 6)$ and $\alpha$ $(1 \rightarrow 4)$ glucan-bonded protein-polysaccharide complex was $36.95 \%$. The absolute predominance of glucose observed was indicated by the presence of the acetylated derivatives of glucose on chromatograms [26]. Considering the complex 
TABle 3: Analgesic activity for the purified polysaccharides and isolated fractions.

\begin{tabular}{lcc}
\hline Samples & Number of abdominal writhing/20 min & \% Inhibition of abdominal writhing \\
\hline Positive control & $29.7 \pm 0.06$ & - \\
Purified polysaccharide & $4.2 \pm 0.49$ & $85.95 \pm 0.17$ \\
F1 & $4.2 \pm 0.37$ & $85.98 \pm 0.17$ \\
F2 & $3.9 \pm 0.37$ & $87.03 \pm 0.05$ \\
F3 & $2.6 \pm 0.47$ & $91.26 \pm 0.02$ \\
\hline
\end{tabular}

constitution of the samples analyzed, quantification was not considered. Analysis of Agaricus blazei grown in Japan [10] revealed contents in the order of $38-45 \%$. Fractions isolated from fruit bodies of Lentinus edodes presented carbohydrate contents of 74.9-99.2\%, which demonstrates the diverse constituent contents for different species [39]. In species Schizophyllum commune and Lentinus edodes from India, the protein content is around 16 and $23 \%$ with amino acid contents of 34 and $39 \%$ [40].

Reduction in the carbohydrate content was observed in the order the fractions were obtained, F1 (39.58\%), F2 (33.84\%), and F3 (15.62\%) as observed in Table 1. The same authors reported reduction in the characteristic carbohydrate bands of the fractions from F1 to F3 by FTIR spectroscopy [35], thus corroborating the behavior described in this work for the reduction of the carbohydrate contents and increase of protein contents with subsequent precipitation of the fractions. That behavior is expected as the fractionation method is based on selective molar mass precipitation. In turn, it was observed that the protein content increases in the order of fraction separation (Table 1). Apparently, the protein content is smaller in larger molecules, which precipitate first, or probably the protein is excluded from the first fractions by some selective process [35].

3.3. Determination of Metal Cations by ICP-AES. The elements identified in the isolated polysaccharide are presented in Table 2. The most significant contents in $\mu \mathrm{g} / \mathrm{g}$ were $\mathrm{P}$ (23024.90), K (12571.60), and $\mathrm{Na}$ (4550.10). The mineral composition revealed to be important for human nutrition. Elements such as $\mathrm{Na}$ and $\mathrm{K}$ present considerable force and ionic mobility and may be related to the action mechanism of polysaccharides. Additionally, it is of fundamental importance that no heavy metals were detected. As the mineral content of mushrooms is related to the growth region, it is common to observe variation in the mineral contents of mushrooms of different origins. However, regardless of the origin, apparently potassium $(\mathrm{K})$ and phosphorus $(\mathrm{P})$ were the major elements in most mushrooms [12, 13, 41]. Among the most researched species are Basidiomycetes and Ascomycetes, which encompass most edible mushrooms such as Agaricus bisporus, Pleurotus ostreatus, and Lentinus edodes, besides Agaricus blazei.

3.4. Analgesic Activity Assay. Considering the percent inhibition of abdominal writhing (Table 3), it can be observed that the analgesic activity was significant for all samples tested. The dose of $20 \mathrm{mg} / \mathrm{kg}$ presented an effective analgesic action.
Abdominal writhing induction is based on the injection of a potent chemical stimulant such as acetic acid to provide a short-term an algesic response. The inhibition of the nociceptive response by drugs such as antihistamines, hypotensors, and those affecting central nervous system renders the model unspecific and advantageous [42]. Acetic acid does not bind to the peritoneal nociceptive receptors directly. In this way, the induction of pain occurs through the liberation of endogenous substances such as prostaglandins, which excite nerve ends and produce acute inflammation in the peritoneal area [43]. The analgesic activity of some sulphated polysaccharides algae was researched by the same method, and writing inhibition values of 63-93\% were recorded [44]. In an attempt to relate the increase in analgesic action to some property, it can be considered that the increase in analgesic response (F1 and $\mathrm{F} 3$ ) was larger for the fraction with larger protein content. In contrast, in an earlier NMR characterization of fractions by the same authors [35], it was observed that of the three fractions F3 was the richest in $\beta$-glucan $(1 \rightarrow 6)$, the one reported in literature as having the most effective pharmacological response relative to antitumoral and immunosuppressing activities among others [10, 38, 45]. Suseem et al. [5] observed antinociceptive activity by $P$. eous. They consider that the significant reduction in acetic acidinduced writhes (analgesic effect) may be via central mechanisms involving receptor systems or peripherally mediated via inhibition of synthesis and release of prostaglandins, leukotrienes, and other endogenous substances that are involved in inflammation and pain. That may be considered as a mechanism of action for Agaricus blazei Murill.

\section{Conclusion}

The fruit body of Agaricus blazei Murill showed to be rich in proteins and mineral elements (mainly $\mathrm{K}, \mathrm{P}$, and $\mathrm{Ca}$ ). The glycoprotein complex isolated from Agaricus blazei Murill is constituted mainly of $\beta$-glucan $(1 \rightarrow 6)$, protein content of $17.24 \%$, and total carbohydrate content of $36.95 \%$. The main minerals present $(\mathrm{K}, \mathrm{P}, \mathrm{Na}$, and $\mathrm{Ca})$ along with the other constituents show that this mushroom is a valuable nutrient. Furthermore, the analgesic activity assay gave promising results in mice with an abdominal writhing inhibition value of between 85.95 and $91.26 \%$. The best analgesic response was that of the fraction with the largest protein content along with the largest amount of $\beta$-glucan $(1 \rightarrow 6)$. These results support the evidence that the pharmacological activity exhibited by Agaricus polysaccharides is mainly related to the presence of $\beta$-glucans. 


\section{References}

[1] H. S. Yim, F. Y. Chye, S. M. Koo, P. Matanjun, S. E. How, and C. W. Ho, "Optimization of extraction time and temperature for antioxidant activity of edible wild mushroom, Pleurotus porrigens," Food and Bioproducts Processing, vol. 90, no. 2, pp. 235-242, 2012.

[2] J. Y. Lee, J. Y. Kim, Y. G. Lee, M. H. Rhee, E. K. Hong, and J. Y. Cho, "Molecular mechanism of macrophage activation by exopolysaccharides from liquid culture of Lentinus edodes," Journal of Microbiology and Biotechnology, vol. 18, no. 2, pp. 355364, 2008.

[3] C. G. Son, J. W. Shin, J. H. Cho et al., "Macrophage activation and nitric oxide production by water soluble components of Hericium erinaceum," International Immunopharmacology, vol. 6, no. 8, pp. 1363-1369, 2006.

[4] E. R. Carbonero, C. R. Andrea, C. S. Freitas et al., "Chemical and biological properties of a highly branched beta-glucan from edible mushroom Pleurotus sajor-caju," Carbohydrate Polymers, vol. 90, pp. 814-819, 2012.

[5] S. R. Suseem, S. A. Mary, R. P. Neelakanda, and G. Marslin, "Evaluation of the analgesic activity of ethyl acetate, methanol and aqueous extracts of Pleurotus eous mushroom," Asian Pacific Journal of Tropical Medicine, vol. 4, no. 2, pp. 117-120, 2011.

[6] P. Manzi, L. Gambelli, S. Marconi, V. Vivanti, and L. Pizzoferrato, "Nutrients in edible mushrooms: an inter-species comparative study," Food Chemistry, vol. 65, no. 4, pp. 477-482, 1999.

[7] A. T. Southgate, K. Waldron, I. T. Johnson, and G. R. Fenwich, "Dietary fibre: chemical and biological aspects," Special Publication 83, Royal Society of Chemistry, 1990.

[8] P. C. K. Cheung, "Plasma and hepatic cholesterol levels and fecal neutral sterol excretion are altered in hamsters fed straw mushroom diets," Journal of Nutrition, vol. 128, no. 9, pp. 15121516, 1998.

[9] H. Kawagishi, T. Kanao, R. Inagaki et al., "Formolysis of a potent antitumor $(1 \rightarrow 6)$ - $\beta$-d-glucan-protein complex from Agaricus blazei fruiting bodies and antitumor activity of the resulting products," Carbohydrate Polymers, vol. 12, no. 4, pp. 393-403, 1990.

[10] T. Mizuno, T. Hagiwara, T. Nakamura, H. Ito, K. Shimura, and T. Sumiya, "Antitumoraktivity and some properties of watersoluble polysaccharides from Himematsutake, the fruiting body of Agaricus blazei Murill," Agricultural and Biological Chemistry, vol. 54, pp. 2889-2896, 1990.

[11] H.-L. Chang, G.-R. Chao, C.-C. Chen, and J.-L. Mau, "Nonvolatile taste components of Agaricus blazei, Antrodia camphorata and Cordyceps militaris mycelia," Food Chemistry, vol. 74, no. 2, pp. 203-207, 2001.

[12] M. Nikkarinen and E. Mertanen, "Impact of geological origin on trace element composition of edible mushrooms," Journal of Food Composition and Analysis, vol. 17, no. 3-4, pp. 301-310, 2004.

[13] L. Rácz, L. Papp, V. Oldal, and Z. Kovács, "Determination of essential and toxic metals in cultivated champignons by inductively coupled plasma atomic emission spectrometry," Microchemical Journal, vol. 59, no. 2, pp. 181-186, 1998.

[14] V. Mohaček-Grošev, R. Božac, and G. J. Puppels, "Vibrational spectroscopic characterization of wild growing mushrooms and toadstools," Spectrochimica Acta A, vol. 57, no. 14, pp. 2815-2829, 2001.
[15] V. E. C. Ooi and F. Liu, "Immunomodulation and anti-cancer activity of polysaccharide-protein complexes," Current Medicinal Chemistry, vol. 7, no. 7, pp. 715-729, 2000.

[16] P. Manzi and L. Pizzoferrato, "Beta-glucans in edible mushrooms," Food Chemistry, vol. 68, no. 3, pp. 315-318, 2000.

[17] P. Orlean, "Biogenesis of yeast cell wall and surface components," in The Molecular and Cellular Biology of the Yeast Saccharomyces, J. R. Pringle, J. R. Broach, and E. W. Jones, Eds., vol. 3 of Cell Cycle and Cell Biology, pp. 229-362, Cold Spring Harbor Laboratory Press, New York, NY, USA, 1997.

[18] Y. Sun, J. Tang, X. Gu, and D. Li, "Water-soluble polysaccharides from Angelica sinensis (Oliv.) Diels: preparation, characterization and bioactivity," International Journal of Biological Macromolecules, vol. 36, no. 5, pp. 283-289, 2005.

[19] T. B. Ng, "A review of research on the protein-bound polysaccharide (polysaccharopeptide, PSP) from the mushroom Coriolus versicolor (basidiomycetes: polyporaceae)," General Pharmacology, vol. 30, no. 1, pp. 1-4, 1998.

[20] D. Rout, S. Mondal, I. Chakraborty, and S. S. Islam, "The structure and conformation of a water-insoluble $(1 \rightarrow 3)-,(1 \rightarrow$ 6)- $\beta$-d-glucan from the fruiting bodies of Pleurotus florida," Carbohydrate Research, vol. 343, no. 5, pp. 982-987, 2008.

[21] M. S. Shiao, K. R. Lee, J. J. Lin, and C. T. Wang, Food Phytochemicals For Cancer Prevention II: Teas, Spices and Herbs, The American Chemical society, Washington, DC, USA, 1994.

[22] S. C. Jong and J. M. Birmingham, "Medicinal benefits of the mushroom Ganoderma," Advances in Applied Microbiology, vol. 37, pp. 101-134, 1992.

[23] C.-W. Lieu, S.-S. Lee, and S.-Y. Wang, "The effect of Ganoderma lucidum on induction of differentiation in leukemic U937 cells," Anticancer Research, vol. 12, no. 4, pp. 1211-1215, 1992.

[24] W. D. Jarvis, A. J. Turner, L. F. Povirk, R. S. Traylor, and S. Grant, "Induction of apoptotic DNA fragmentation and cell death in HL-60 human promyelocytic leukemia cells by pharmacological inhibitors of protein kinase C," Cancer Research, vol. 54, no. 7, pp. 1707-1714, 1994.

[25] L. C. Faccin, F. Benati, V. P. Rincão et al., "Antiviral activity of aqueous and ethanol extracts and of an isolated polysaccharide from Agaricus brasiliensis against poliovirus type 1," Letters in Applied Microbiology, vol. 45, no. 1, pp. 24-28, 2007.

[26] J. P. F. Angeli, L. R. Ribeiro, M. L. C. Gonzaga et al., "Protective effects of $\beta$-glucan extracted from Agaricus brasiliensis against chemically induced DNA damage in human lymphocytes," Cell Biology and Toxicology, vol. 22, no. 4, pp. 285-291, 2006.

[27] M. L. C. Gonzaga, Agaricus Blazei Murill: Isolamento, Caracterização Estrutural e Atividades Biológicas dos Polissacarídeos elou Glicoconjugados Presentes [Ph.D. thesis], Federal University of Ceará, Ceará, Brazil, 2006.

[28] Y. Yoshioka, R. Tabeta, H. Saitó, N. Saitó, and F. Fukuoka, "Antitumor Polysaccharides From P. Ostreatus (Fr.) Quél.: Isolation and Structure of a beta-Glucan," Carbohydrate Research, vol. 140, pp. 93-100, 1985.

[29] M. Dubois, K. A. Gilles, J. K. Hamilton, P. A. Rebers, and F. Smith, "Colorimetric method for determination of sugars and related substances," Analytical Chemistry, vol. 28, no. 3, pp. 350356, 1956.

[30] M. Pramanik, S. Mondal, I. Chakraborty, D. Rout, and S. S. Islam, "Structural investigation of a polysaccharide (Fr. II) isolated from the aqueous extract of an edible mushroom, Pleurotus sajor-caju," Carbohydrate Research, vol. 340, no. 4, pp. 629-636, 2005. 
[31] E. F. Hartree, "Determination of protein: a modification of the lowry method that gives a linear photometric response," Analytical Biochemistry, vol. 48, no. 2, pp. 422-427, 1972.

[32] M. M. Bradford, "A rapid and sensitive method for the quantitation of microgram quantities of protein utilizing the principle of protein dye binding," Analytical Biochemistry, vol. 72, no. 1-2, pp. 248-254, 1976.

[33] W. C. Vander and S. Margolin, "Analgesic tests based upon exerimentally induced acute abdominal pain in rats," Federation Proceedings, vol. 15, article 494, 1956.

[34] R. Koster, M. Anderson, and J. Beer, "Acetic acid for analgesic screening," Federation Proceedings, vol. 18, pp. 412-414, 1959.

[35] M. L. C. Gonzaga, N. M. P. S. Ricardo, F. Heatley, and S. D. A. Soares, "Isolation and characterization of polysaccharides from Agaricus blazei Murill," Carbohydrate Polymers, vol. 60, no. 1, pp. 43-49, 2005.

[36] S. Saito, Y. Sasaki, T. Furumoto, S. Sumita, and T. Hinomoto, "Virtual ${ }^{1} \mathrm{H}-{ }^{1} \mathrm{H}$ spin-spin coupling in a linear five-spin system on the pyranose rings of some glucuronides," Carbohydrate Research, vol. 258, pp. 59-75, 1994.

[37] R. M. Silvestein, G. C. Bassler, and T. C. Morrill, Identificação Espectrométrica de Compostos Orgânicos, Guanabara Koogan, 1994.

[38] I. Chakraborty, S. Mondal, M. Pramanik, D. Rout, and S. S. Islam, "Structural investigation of a water-soluble glucan from an edible mushroom, Astraeus hygrometricus," Carbohydrate Research, vol. 339, no. 13, pp. 2249-2254, 2004.

[39] Y. Ukawa, H. Ito, and M. Hisamatsu, "Antitumor effects of $(1 \rightarrow$ $3)$ - $\beta$-D-glucan and $(1 \rightarrow 6)-\beta$-D-glucan purified from newly cultivated mushroom, Hatakeshimeji (Lyophyllum decastes Sing.)," Journal of Bioscience and Bioengineering, vol. 90, no. 1, pp. 98-104, 2000.

[40] T. Longvah and Y. G. Deosthale, "Compositional and nutritional studies on edible wild mushroom from northeast India," Food Chemistry, vol. 63, no. 3, pp. 331-334, 1998.

[41] A. Demirbaş, "Concentrations of 21 metals in 18 species of mushrooms growing in the East Black Sea region," Food Chemistry, vol. 75, no. 4, pp. 453-457, 2001.

[42] L. C. Hendershot and J. Forsaith, "Antagonism of the frequency of phenylquinone-induced writhing in the mouse by weak analgesics and nonanalgesics," Journal of Pharmacology and Experimental Therapeutics, vol. 125, pp. 237-240, 1959.

[43] B. J. Northover, "The permeability to plasma proteins of the peritoneal blood vessels of the mouse, and the effect of substances that alter permeability," The Journal of pathology and bacteriology, vol. 85, pp. 361-370, 1963.

[44] L. A. P. Vieira, Estudos Bioquímicos e Farmacológicos das Algas, Bryothamnion seaforthii, Bryothamnion triquetrum e Bottuocladia occidentalis [M.S. thesis], Federal University of Ceará, Ceará, Brazil,, 2002.

[45] L. Pires, P. A. J. Gorin, F. Reicher, and M.-R. Sierakowski, "An active heparinoid obtained by sulphation of a galactomannan extracted from the endosperm of Senna macranthera seeds," Carbohydrate Polymers, vol. 46, no. 2, pp. 165-169, 2001. 

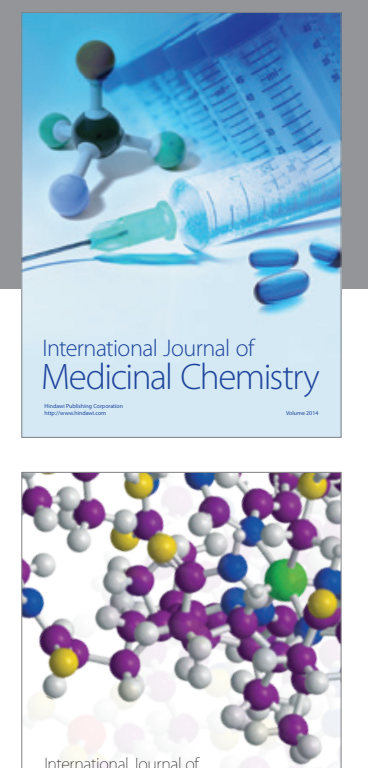

\section{Carbohydrate} Chemistry

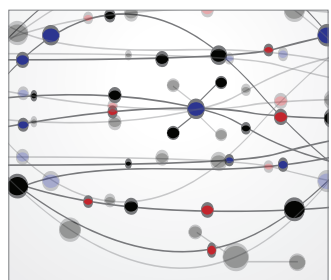

The Scientific World Journal
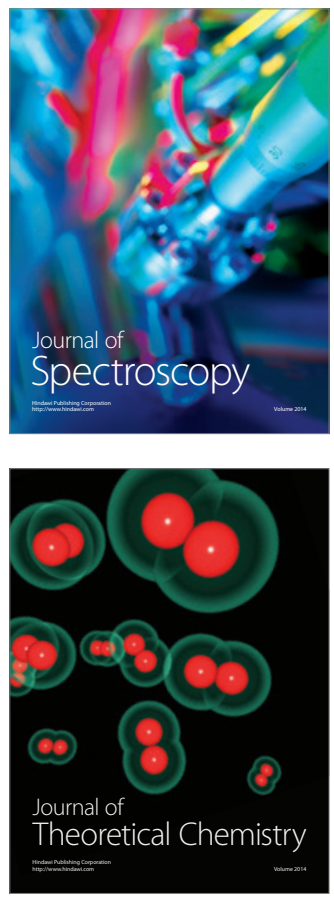
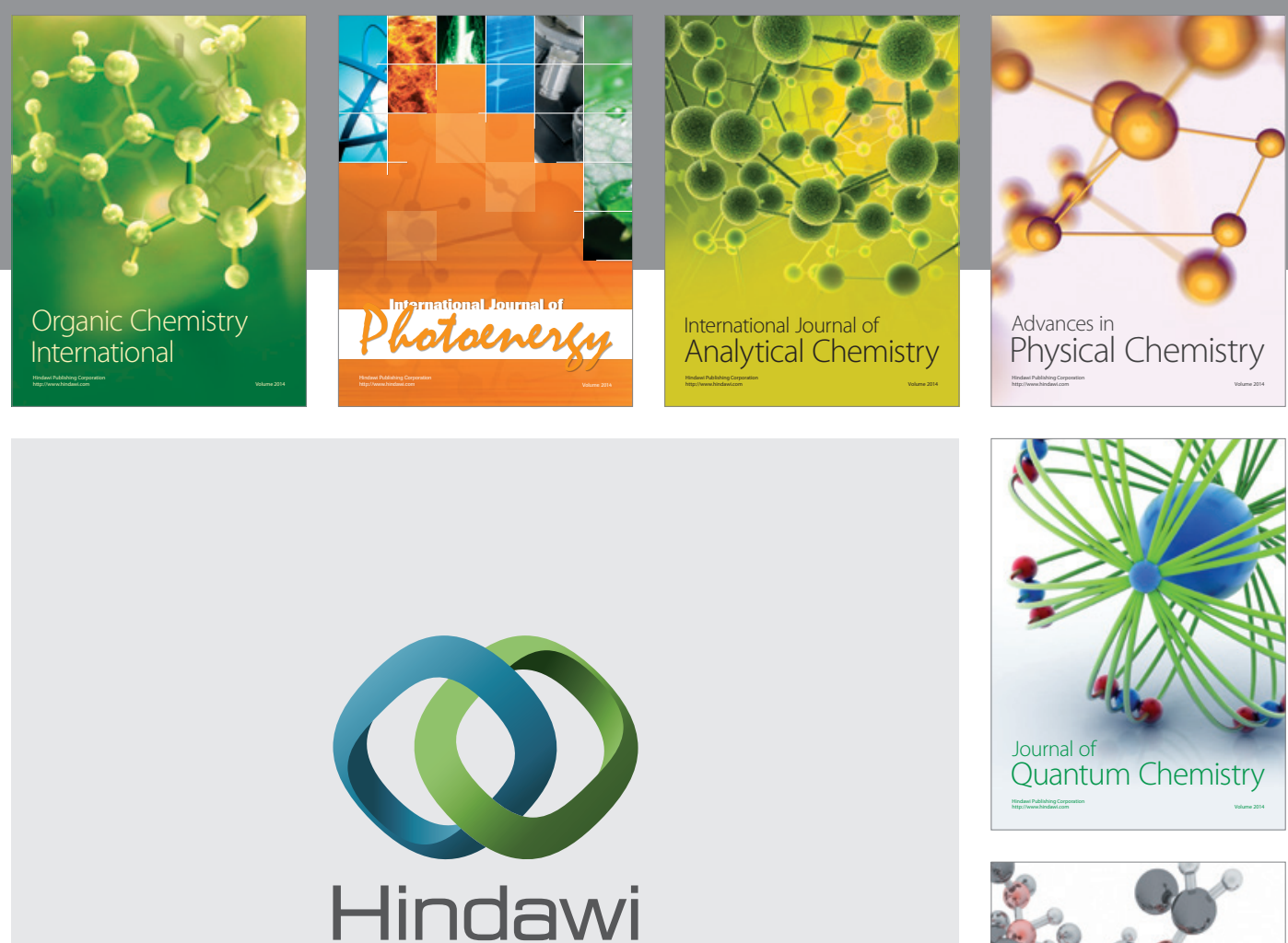

Submit your manuscripts at

http://www.hindawi.com

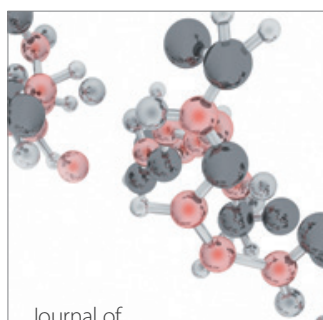

Analytical Methods

in Chemistry

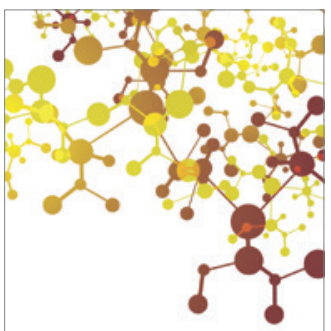

Journal of

Applied Chemistry

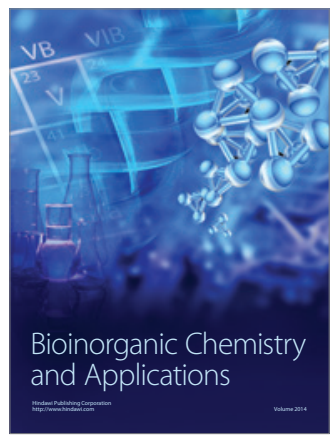

Inorganic Chemistry
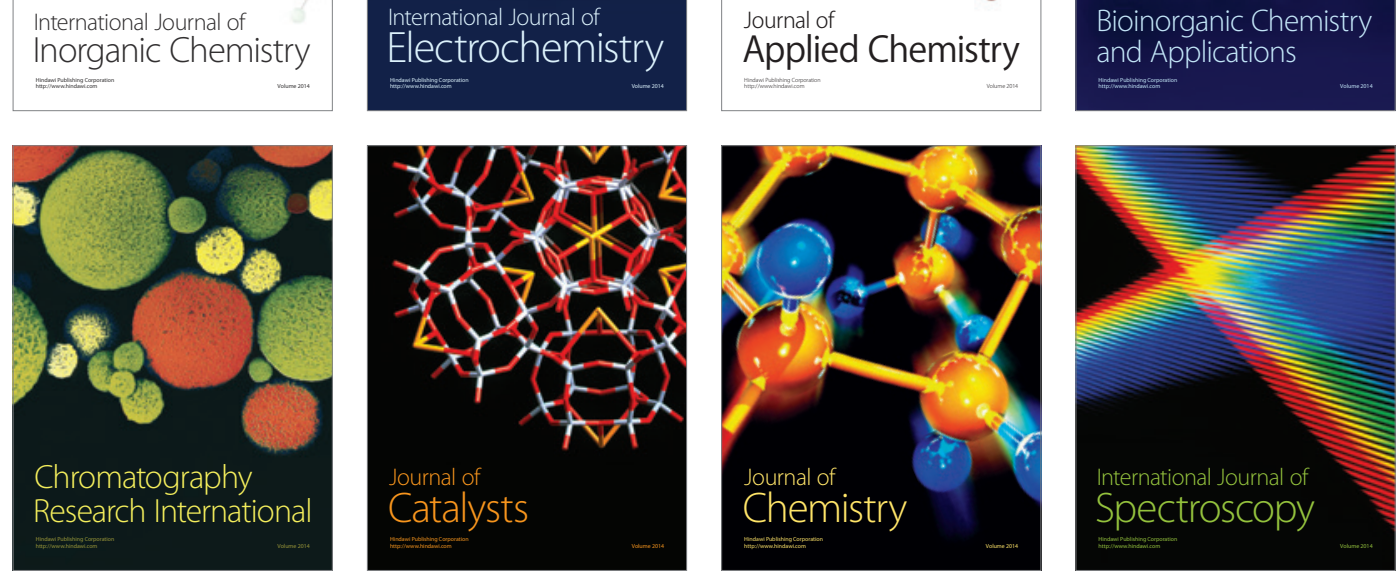